\title{
PROFIL PENYESUAIAN SOSIAL REMAJA YANG MENGALAMI KECANDUAN MENGAKSES FACEBOOK
}

\author{
Pia Amanda Nurhusni ${ }^{1}$
}

\begin{abstract}
Social Adjustment Profiles Adolescence Who Have Access addicted to Facebook. The process of social adjustment of students who disrupted it can cause problems in the fulfillment of their needs. The research objective of this thesis to obtain social adjustment eighth grade students of SMP Negeri 15 Bandung who had access facebook addiction. The study used descriptive research methods. Questionnaire used was a questionnaire addiction accessing facebook and social adjustment. The results: (1) Addiction adolescence including access facebook high category and (2) the social adjustment of adolescence who access facebook categorized as low, medium and high, (3) the design of personal-social counseling services focus on reducing access facebook addiction indicators and development indicators of social adjustment.
\end{abstract}

Keywords: Addiction, Facebook, Social Adjustment, Personal-Social Counseling.

INDONESIAN JOURNAL OF EDUCATIONAL COUNSELING

Website: http://ojs.ejournal.id/index.php/ijec

Permalink: http://ojs.ejournal.id/index.php/ijec/article/view/119

How to cite (APA): Nurhusni, P. A. (2017). Profil penyesuaian sosial remaja yang mengalami kecanduan mengakses facebook. Indonesian Journal of Educational Counseling, 1(2), 129-144.

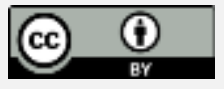

This is an open access article distributed under the terms of the Creative Commons Attribution 4.0 International License, which permits unrestricted use, distribution, and reproduction in any medium, provided the original work is properly cited.

\section{PENDAHULUAN}

Masa remaja merupakan masa transisi, pada periode ini secara usia, individu baru saja lepas dari masa kanak-kanak yang ditandai dengan mulai menunjukkan perilaku mandiri yakni tidak lagi selalu bergantung pada orang tua tetapi juga belum dapat dianggap dewasa karena individu pada rentang usia ini belum sepenuhnya siap untuk dibiarkan mandiri sehingga para orang tua masih harus memberikan arahan. Hurlock (1997: 207) mengungkapkan bahwa salah satu ciri pada masa remaja adalah masa remaja sebagai periode perubahan.

Hurlock lebih lanjut menjelaskan bahwa terdapat empat perubahan yang sama yang hampir bersifat universal. Pertama, meningginya emosi yang intensitasnya bergantung pada tingkat perubahan fisik dan psikologis yang terjadi. Kedua, perubahan tubuh, minat dan peran yang diharapkan oleh

\footnotetext{
${ }^{1}$ Departemen Psikologi Pendidikan dan Bimbingan, FIP Universitas Pendidikan Indonesia.
} 
kelompok sosial, menimbulkan masalah. Ketiga, dengan berubahnya minat dan perilaku, maka nilai-nilai juga berubah. Apa yang pada masa kanak-kanak dianggap penting, sekarang hampir dewasa tidak penting lagi. Keempat, sebagian besar remaja bersikap ambivalen terhadap setiap perubahan, mereka menginginkan dan menuntut kebebasan tetapi mereka sering takut bertanggung jawab akan akibatnya dan meragukan kemampuan mereka untuk dapat mengatasi tanggung jawab tersebut.

Perubahan-perubahan yang di alami remaja ini salah satunya merupakan akibat dari adanya interaksi sosial antara dirinya dengan lingkungan sekitarnya terutama peergroupnya seperti yang dikemukakan oleh Conger (Koban, online) bahwa Perkembangan sosial pada masa remaja lebih melibatkan kelompok teman sebaya dibanding orang tua. Dibanding pada masa kanakkanak, remaja lebih banyak melakukan kegiatan di luar rumah seperti kegiatan sekolah, ekstra kurikuler dan bermain dengan teman. Pendapat yang disampaikan Conger tadi memberi penguatan mengenai besarnya peran kelompok teman sebaya dalam perkembangan di masa remaja.

Pada diri remaja, pengaruh lingkungan dalam menentukan perilaku diakui cukup kuat. Walaupun remaja telah mencapai tahap perkembangan kognitif yang memadai untuk menentukan tindakannya sendiri, namun penentuan diri remaja dalam berperilaku banyak dipengaruhi oleh tekanan dari kelompok teman sebaya (Papalia, D E., Olds, S. W., \& Feldman, Ruth D., 2001).

Ketika remaja sudah berada dalam suatu lingkungan maka kondisi tersebut mendorong remaja untuk melakukan sebuah interaksi sosial. Bonner (Ahmadi, 1999: 54) memberikan rumusan mengenai interaksi sosial, yakni, suatu hubungan antara dua individu atau lebih, dimana kelakuan individu yang satu mempengaruhi, mengubah atau memperbaiki kelakuan individu lain atau sebaliknya. Chaplin (1983) mendefinisikan bahwa interaksi merupakan hubungan sosial antara beberapa individu yang mana individu-individu itu mempengaruhi satu sama lain secara serempak

Berdasarkan dua pendapat ahli di atas dapat dipahami bahwa dari suatu interaksi sosial yang dilakukan oleh individu akan saling berdampak atau mempengaruhi terhadap individu lainnya sehingga dapat mengubah atau memperbaiki perilaku individu. Schneider (1964: 454) mengemukakan tentang penyesuaian sosial bahwa:

Sosial adjustment signifies the capacity to react affectively and wholesomely to sosial realities, situation and relations do that the requirement for sosial living are fulfilled in an acceptable and satisfactory manner.

Berdasarkan pendapat tersebut maka dapat dipahami bahwa penyesuaian sosial merupakan kemampuan individu untuk bereaksi secara efektif dan sehat terhadap realitas sosial, situasi dan hubungan sosial sehingga individu dapat melakukan pemenuhan kebutuhan dengan perilaku yang memuaskan dan cara yang dapat diterima. 
Menurut Gerungan (1988: 180) faktor-faktor yang mempengaruhi penyesuaian sosial adalah sebagai berikut: (1) peran keluarga yang meliputi status sosial ekonomi, kebutuhan keluarga, sikap dan kebiasaan orang tua dan status anak, (2) peranan sekolah meliputi struktural dan organisasi sekolah, peranan guru dalam kegiatan belajar mengajar (KBM), (3) peranan lingkungan kerja misalnya lingkungan pekerjaan industri atau pertanian di daerah, (4) peranan media massa, besarnya pengaruh alat komunikasi seperti perpustakaan, televisi, film, radio, internet dan sebagainya.

Berkenaan dengan peranan media dan pengaruh alat komunikasi, di Indonesia akhir-akhir ini dalam berbagai media baik itu media cetak maupun media elektronik ramai diberitakan mengenai tingginya minat para remaja dalam penggunaan situs jejaring sosial sebagai media untuk bersosialisasi. Situs jejaring sosial ini terdiri atas beragam jenis seperti myspace, friendster, yahoo messanger, facebook, koprol, plurk, twitter dan lain-lain.

Pengguna facebook di Indonesia (2010-2011) mencapai lebih dari 31,7 juta. Dengan populasi online $100 \%$, Indonesia menguasai $5,56 \%$ dari total pengguna Facebook di dunia. Berdasarkan gender, pengguna lelaki lebih mendominasi di Indonesia, yakni sekitar 18,7 juta (59,1\%) dibandingkan wanita yang jumlahnya diestimasi sekitar 12,9 juta $(40,9 \%)$. Sedangkan, berdasarkan usia, 18-24 tahun merupakan rentang usia terbesar, yakni 13,1 juta pengguna $(41,5 \%)$. Disusul rentang usia remaja 14-17 tahun sebesar 8 juta pengguna $(25,4 \%)$, lalu rentang usia $25-34$ tahun sebesar 6,8 juta pengguna $(21,6 \%)$. Sisanya, tidak lebih dari 20 persen. Untuk rentang usia 35-44 tahun, penggunanya sekitar 2 juta pengguna (6,2\%). Sementara rentang usia 44-54 tahun, ada sekitar 525 ribu pengguna (1,7\%), setara dengan rentang usia 55 tahun ke atas, sekitar 500 ribu (1,7\%). Porsi pengguna anak-anak, atau 13 tahun ke bawah, terhitung 615 ribu (1,9\%) (Satrio, 2011)

Setiap hal tentunya memiliki dampak positif dan negatif tersendiri. Begitu pula dengan keberadaan situs jejaring sosial dan kebiasaan siswa dalam mengaksesnya. Penelitian yang dilakukan oleh Stony Brook University, New York, mengatakan bahwa kebiasaan mengakses situs jejaring sosial dapat menyebabkan depresi. Dari hasilnya ditemukan bahwa anak-anak yang suka menceritakan kehidupan dan pikiran mereka melalui Facebook, memiliki tingkat depresi yang lebih tinggi (Wahdah, 2016). Hasil studi pendahuluan menunjukkan bahwa di kelas VIII E SMP Negeri 15 Bandung sebanyak hampir 90\% menunjukkan gejala kecenderungan mengakses situs jejaring sosial facebook.

Perilaku siswa yang mengakses facebook ketika jam pelajaran masih berlangsung apabila dibiarkan begitu saja dapat memicu terjadinya perilaku kecanduan dalam mengakses facebook. Hal ini senada dengan pendapat yang diungkapkan Juan (Ubaya, Online) bahwa ketika siswa mulai lupa waktu, kemudian mengurangi waktu efektif kegiatan penting seperti belajar untuk 
digunakan mengakses internet dalam hal ini facebook maka siswa sudah mulai menunjukkan tanda-tanda atau gejala perilaku kecanduan facebook.

Hasil studi pendahuluan dan analisis para pengamat teknologi sedikit banyak berpengaruh terhadap interaksi sosial siswa, sedangkan dalam suatu interaksi sosial siswa tersebut harus melakukan penyesuaian sosial dengan lingkungan dimana siswa tersebut berada. Hal ini diperkuat oleh pendapat Moss dan Townsend (Halim, 2008: 62) yang menyatakan bahwa pemanfaatan kemajuan teknologi juga mengurangi kesempatan untuk saling berinteraksi dengan orang-orang dalam jarak sosial mereka. Perubahan fisik kota secara pesat dan semakin besar, sebuah pemandangan sosial baru juga muncul. Penggunaan pribadi teknologi komunikasi yang meluas di ruang-ruang publik telah menghilangkan garis batas dan protokol antara ruang publik dan ruang pribadi. Batas-batas antara rumah, kantor, sarana angkutan, dan jalan menjadi semakin kabur.

Layanan bimbingan dan konseling yang juga memiliki layanan khusus aspek pribadi sosial perlu untuk mewaspadai dampak-dampak yang ditimbulkan dari pemanfaatan kemajuan teknologi internet dalam hal ini kebiasaan siswa mengakses facebook. Hal ini disebabkan apabila siswa tidak diarahkan pada pemanfaatan facebook yang tepat guna maka dikhawatirkan akan memberikan dampak yang tidak diharapkan baik itu interaksi siswa dengan lingkungan keluarga, lingkungan masyarakat maupun lingkungan sekolah siswa yang akan mengganggu penyesuaian sosial siswa dengan lingkungannya.

\section{METODE}

Pendekatan penelitian yang dilakukan adalah dengan pendekatan deskriptif kuantitatif diselaraskan dengan variabel penelitian yang memusatkan diri pada masalah-masalah aktual dan fenomena yang terjadi pada saat sekarang dengan bentuk hasil penelitian berupa angka-angka yang memiliki makna. Pendekatan deskriptif dimaksudkan untuk memperoleh gambaran yang jelas mengenai profil penyesuaian sosial remaja/siswa kelas VIII SMP Negeri 15 Bandung yang mengalami kecanduan mengakses facebook. Metode ini dipilih karena bermaksud mendeskripsikan, menganalisis dan mengambil suatu generalisasi dari pemaparan yang tidak mendalam. Selanjutnya data tersebut diolah dan dianalisis dengan menggunakan teknik statistik.

Pengumpulan data dilakukan menggunakan instrumen penelitian berupa angket mengenai kecanduan remaja dalam mengakses facebook dan penyesuaian sosial siswa. Teknik yang digunakan merupakan sampling purposive yakni teknik penentuan sampel dengan pertimbangan tertentu.

Teknik analisis data dilakukan setelah semua data terkumpul. Pengolahan data dilakukan melalui bantuan program Microsoft Excel dan SPSS. Setelah keluar 
hasilnya maka dilakukan proses mendeskripsikan dan memberi makna terhadap output.

\section{HASIL DAN PEMBAHASAN}

Hasil rekapitulasi kategorisasi kecanduan mengakses facebook siswa/remaja di SMP Negeri 15 Bandung secara umum disajikan dalam Tabel 1.

Tabel 1. Rekapitulasi Kategorisasi Kecanduan Mengakses Facebook

\begin{tabular}{cccc}
\hline Kategorisasi & Interval & Jumlah Siswa & Persentase \\
\hline Rendah & $\mathrm{X} \leq 74$ & 53 & $16,5 \%$ \\
\hline Sedang & $74 \leq \mathrm{X}<110$ & 212 & $66,0 \%$ \\
\hline Tinggi & $\mathrm{X}>110$ & 56 & $17,4 \%$ \\
\hline & Jumlah & 321 & $100 \%$ \\
\hline
\end{tabular}

Berdasarkan Tabel 1, tampak bahwa kecanduan mengakses facebook remaja/siswa di SMP Negeri 15 Bandung umumnya tergolong pada kategori sedang. Dari 321 responden yang dijadikan sampel dalam penelitian ini, 66,0\% diantaranya atau 212 orang dapat disebut sebagai siswa yang memiliki kecanduan mengakses facebook dengan kategori sedang. 53 orang lainnya atau $16,5 \%$ tergolong pada siswa yang termasuk pada kategori rendah dalam hal kecanduan mengakses facebook. Adapun sisanya sebanyak 56 orang atau $17,4 \%$ dari total responden termasuk siswa yang memiliki kecanduan mengakses facebook dengan kategori tinggi.

Gambaran kecanduan mengakses facebook ini senada dengan hasil penelitian Astutik Nur Qomariyah yang dilakukan pada tahun 2008 bahwa usia remaja saat pertama kali mengenal dan menggunakan internet ialah 12 tahun. Ratarata saat itu mereka telah memasuki kelas VII SMP, dimana tugas-tugas sekolah yang diberikan mulai mengharuskan mereka mencari sumber atau bahan-bahannya di internet sehingga mereka dituntut harus bisa menggunakan internet.

Qomariyah (2008) menyatakan usia responden yang duduk di kelas VIII SMP rata-rata berada di rentang usia 13-14 tahun. Jika di kelas VII SMP mereka sudah mengenal dan dapat mengoperasikan internet maka ketika duduk di kelas VIII ini mereka sudah dapat memanfaatkan fasilitas lain dari internet selain untuk mencari sumber atau bahan-bahan tugas sekolah. Mengoperasikan situs jejaring sosial seperti facebook menjadi salah satu kegiatan yang mereka lakukan setelah mereka mengetahui lebih banyak mengenai fungsi internet.

Hasil penelitian yang menyatakan sekitar $17,4 \%$ dari total responden mengalami kecanduan mengakses facebook dengan kategori tinggi juga sesuai dengan pernyataan David Greenfield (Syahran, 2015: 85) bahwa sekitar $6 \%$ dari pengguna internet mengalami kecanduan. 
Tabel 2. Tingkat Ketercapaian Skor Kecanduan Mengakses Facebook

\begin{tabular}{lccc}
\hline \multicolumn{1}{c}{ Aspek yang diukur } & $\begin{array}{c}\text { Skor } \\
\text { Total }\end{array}$ & $\begin{array}{c}\text { Skor } \\
\text { Ideal }\end{array}$ & $\begin{array}{c}\text { Ketercapaian } \\
(\%)\end{array}$ \\
\hline Salience & 7336 & 15408 & $47,6 \%$ \\
\hline Mood Modification & 7348 & 13482 & $54,5 \%$ \\
\hline Conflict & 4982 & 10593 & $47,0 \%$ \\
\hline Tolerance & 2582 & 5778 & $44,7 \%$ \\
\hline Withdrawl & 3332 & 5778 & $57,7 \%$ \\
\hline Relapse & 4010 & 8667 & $46,3 \%$ \\
\hline
\end{tabular}

Pada Tabel 2 digambarkan persentase ketercapaian setiap aspek dalam kecanduan mengakses facebook di kelas VIII SMPN 15 Bandung. Skor terendah kecanduan mengakses facebook adalah aspek tolerance yakni sebesar $44,7 \%$. Adapun nilai persentase ketercapaian skor tertinggi adalah aspek withdrawl yakni sebesar $57,7 \%$. Berikut pemaparan skor ketercapaian kecanduan mengakses facebook pada setiap aspeknya.

\section{Aspek Salience}

Berdasarkan hasil penelitian yang telah dilakukan, pada gambar 4.4 ditunjukkan bahwa indikator cognitive salience dan behavior salience memberikan kontribusi yang hampir setara terhadap ketercapaian aspek salience. Hal ini ditunjukkan oleh indikator intensitas subjek membayangkan aktivitas mengakses facebook yang mencapai 53,5\% setara dengan persentase yang ditunjukkan indikator subjek menunda aktivitas lain jika sedang mengakses facebook pada behavior salience.

Kesetaraan angka ketercapaian di atas menunjukkan bahwa dominasi mengakses facebook dalam pikiran dan tingkah laku memiliki pengaruh yang sama besarnya dalam mempengaruhi tingkat kecanduan mengakses facebook siswa. Sedangkan untuk angka ketercapaian terendah menunjuk pada indikator jika dihadapkan pada dua pilihan yaitu mengakses facebook atau aktivitas lain maka subjek akan memilih aktivitas mengakses facebook dengan presentase $42,8 \%$.

Perilaku mengakses facebook yang terlalu mendominasi dalam pikiran dan tingkah laku siswa sehari-hari jika dibiarkan terus menerus dapat menimbulkan dampak negatif. Rahmadani (2016: 5) menjelaskan bahwa terlalu sering mengakses situs jejaring sosial seperti facebook dapat menimbulkan dampak negatif salah satunya adalah kurangnya waktu untuk bersosialisasi dan berinteraksi secara langsung dengan orang lain dan lingkungan. Ketika proses sosialisasi dan interaksi siswa mengalami gangguan maka siswa dapat mengalami kesulitan melakukan penyesuaian sosial dalam rangka pemenuhan kebutuhannya di sekolah. Salah satu upaya preventif terhadap dominasi perilaku siswa mengakses facebook di rumah dapat dilakukan melalui pengawasan orang tua. Bentuk pengawasan yang dapat dilakukan oleh orang tua adalah memberikan teguran ketika remaja mulai menunjukkan aktivitas 
mengakses facebook berlebihan atau menjadi teman siswa dalam sistus jejaring sosial facebook, karena sebetulnya ketika facebook menjadi suatu permasalahan ia juga dapat digunakan sebagai alternatif solusi, melalui facebook interaksi orang tua dan anak dapat selalu terhubung (West, Lewis, \& Currie, 2009: 616).

\section{Aspek Mood Modification}

Merasa semakin bersemangat ketika menerima tantangan dalam mengakses facebook menjadi indikator dengan ketercapaian angka paling tinggi dalam aspek mood modification. Indikator ini menunjukkan angka ketercapaian dengan persentase $59,3 \%$.

Bentuk-bentuk tantangan dalam mengakses facebook yang dimaksud dalam penelitian ini diantaranya aplikasi-aplikasi terbaru yang dikeluarkan facebook seperti games, kuis, dan fitur-fitur terbaru dalam penggunaan facebook. Hasil penelitian sejalan dengan pendapat Young, Pistner, O'Mara \& Buchanan (1999) bahwa jenis aplikasi yang digunakan oleh siswa berpengaruh terhadap kecanduan dalam mengakses internet dalam hal ini adalah facebook.

Sebaliknya, indikator kecanduan mengakses facebook pada aspek mood modificationyang paling kecil tingkat persentasenya dibanding indikatorindikator lainnya adalah siswa merasakan perasaan senang pada saat mengakses facebook yakni sebesar 47,7\%.

\section{Aspek Conflict}

Kecanduan mengakses facebook siswa di SMP Negeri 15 Bandung pada aspek conflictlebih disebabkan faktor external conflict, yakni respon keluarga mengenai aktivitas mengakses facebook yang menghabiskan banyak waktu. Hal ini tampak dari tingkat persentase ketercapaian skor kecanduan mengakses facebook siswa/remaja pada indikator tersebut yang mencapai $75,3 \%$, lebih tinggi dari indikator-indikator yang lainnya. Menegur dan memberikan kritikan merupakan beberapa respon yang dilakukan keluarga terhadap aktivitas siswa yang menghabiskan banyak waktu untuk mengakses facebook.

Indikator kecanduan mengakses facebook pada aspek conflictyang paling kecil tingkat persentasenya dibanding indikator-indikator lainnya adalah respon dari teman-teman mengenai waktu luang untuk aktivitas bersama yakni sebesar $39,6 \%$.

Respon keluarga terhadap aktivitas remaja yang menghabiskan banyak waktu untuk mengakses facebook sebaiknya tidak hanya dilakukan dengan memberikan kritik atau teguran, melainkan juga dilakukan dengan upaya memberi pengertian untuk membantu mengurangi tingkat kecanduannya. Lingkungan keluarga menjadi pilar utama yang dapat membantu mereduksi kecanduan siswa mengakses facebook setelah lepas dari lingkungan sekolahnya. Upaya bantuan yang dapat diberikan keluarga salah satunya 
adalah mengarahkan siswa untuk memanfaatkan waktunya lebih efektif, menyalurkan hobi untuk lebih mengaktualisasikan diri siswa. Hal ini senada dengan pendapat Young \& De Abreu (2010: 185) bahwa keluarga dapat membantu mengarahkan siswa pada kegiatan lain, mengisi dengan kegiatan yang lebih menyenangkan dan lebih menyalurkan hobi, serta meluangkan waktu untuk diri sendiri dengan cara membatasi siswa dalam pengggunaan facebook.

\section{Aspek Tolerance}

Berdasarkan gambar 4.7 tampak bahwa kecanduan mengakses facebook siswa di SMP Negeri 15 Bandung pada aspek tolerance lebih disebabkan terjadinya peningkatan durasi waktu yang dihabiskan pada awal mengakses facebook dengan kondisi sekarang. Hal ini tampak dari tingkat persentase ketercapaian skor kecanduan mengakses facebook siswa pada indikator tersebut yang mencapai $48,4 \%$.

Peningkatan durasi ini dapat terjadi karena remaja merasa membutuhkan waktu yang lebih banyak dalam aktivitasnya mengakses facebook. Aktivitas yang biasanya dilakukan remaja ketika mengakses facebook diantaranya chatting dengan teman baik yang dikenalnya di dunia nyata ataupun teman yang baru dikenalnya, aktivitas bermain game, ataupun sekedar membagikan postingan tertentu baik itu di halaman facebook mereka atau di halaman facebook orang lain. Sikap toleransi yang ditunjukkan siswa dalam aspek tolerance ini adalah siswa selalu memberi toleransi penambahan waktu untuk mengakses facebook. Perilaku siswa yang terus menerus memberi toleransi kepada dirinya sendiri untuk mengakses facebook maka hal ini dapat menyebabkan siswa menjadi tidak mempu melakukan manajemen waktu dengan baik. Hal ini dibuktikan dengan hasil penelitian bahwa sekitar $41 \%$ siswa belum dapat mengatur waktu untuk mengakses facebook.

\section{Aspek Withdrawal}

Aspek withdrawl didominasi oleh indikator munculnya perasaan cemas pada diri siswa jika tidak mengakses facebook. Hal ini tampak dari tingkat persentase ketercapaian skor kecanduan mengakses facebook remaja pada indikator tersebut yang mencapai $60,0 \%$. Perasaan cemas siswa muncul karena siswa khawatir ketika mereka sedang offline ada postingan yang menjelek-jelekkan muncul di halaman facebook mereka. Kekhawatiran lain yang muncul ketika siswa sedang offline adalah adanya postingan yang kurang layak dari orang-orang yang kurang bertanggung jawab seperti gambar porno atau kata-kata kasar di halaman facebook mereka. Biasanya kekhawatiran seperti ini dirasakan oleh siswa yang akunnya tidak memiliki sistem keamanan yang baik, memiliki teman facebook yang tidak benar-benar dikenalnya, dan siswa tersebut banyak menampilkan hal-hal yang bersifat pribadi di dalam facebook-nya. Hal-hal yang bersifat pribadi yang banyak ditampilkan oleh siswa dalam facebook-nya adalah foto-foto pribadi mereka dan identitas 
sekolah mereka, hal ini sesuai dengan pendapat Maria (2008: 1) bahwa "70\% dari profil online remaja di situs jejaring sosial, seperti facebook dan MySpace, setengah dari jumlah tersebut memposting informasi pribadi mereka, selain itu $73 \%$ siswa sekolah menengah pertama mengungkapkan nama asli mereka, $30 \%$ mengidentifikasi sekolah mereka, dan 53\% memasang foto mereka sendiri".

\section{Aspek Relapse}

Kecanduan mengakses facebook siswa di SMP Negeri 15 Bandung pada aspek relapselebih disebabkan karena siswa melakukan kembali kegiatan mengakses facebook setelah sebelumnya berhasil untuk menghentikan kegiatan tersebut. Hal ini tampak dari tingkat persentase ketercapaian skor kecanduan mengakses facebook siswa pada indikator tersebut yang mencapai $47,5 \%$ lebih tinggi dari indikator-indikator yang lainnya. Sebaliknya, indikator kecanduan mengakses facebook pada aspek relapseyang paling kecil tingkat persentasenya dibanding indikator-indikator lainnya adalah intensitas mengakses facebook yang bertambah setelah sempat mengalami penghentian yakni sebesar $44,1 \%$.

Aktivitas siswa mengulangi pola awal saat pertama kali mereka mengalami kecanduan mengakses facebook biasanya dilakukan ketika siswa memang belum dapat mengontrol diri mereka secara penuh untuk berhenti mengakses facebook. Pemenuhan kebutuhan mereka yang hanya bisa difasilitasi oleh facebook juga dapat menjadi penyebab siswa kembali mengulangi pola awal mengakses facebook. Pemenuhan kebutuhan yang diberikan facebook yang tidak dimiliki media lain diantaranya adalah memposting foto untuk mengabarkan keadaan terbaru mereka pada teman yang jauh atau sudah lama tidak bertemu, chatting dengan biaya yang murah dan dapat dilakukan kapan saja sesuai keinginan siswa, aktivitas bermain game tanpa perlu membeli program terlebih dahulu seperti games-games yang biasa mereka temui dalam komputer. Hal ini senada dengan spekulasi Griffiths (2000: 217) bahwa karakteristik struktural dari perangkat lunak menjadi media promosi untuk melakukan interaksi dan hal ini cenderung mengarahkan ke dalam perilaku kecanduan.

Pada Tabel 3 tampak bahwa penyesuaian sosial siswa/remaja yang mengalami kecanduan mengakses facebook di SMP Negeri 15 Bandung umumnya tergolong pada kategori sedang dan tinggi. Dari 56 siswa yang mengalami kecanduan mengakses facebook dalam penelitian ini, 75,0\% diantaranya atau 42 orang dapat disebut sebagai siswa yang memiliki penyesuaian sosial dengan kategori tinggi. Adapun sisanya sebanyak 14 orang atau $25,0 \%$ dari total siswa yang mengalami kecanduan mengakses facebook memiliki penyesuaian sosial siswa dengan kategori sedang. 
Tabel 3. Rekapitulasi Kategorisasi Penyesuaian Sosial Remaja yang Mengalami Kecanduan Mengakses Facebook

\begin{tabular}{cccc}
\hline Kategorisasi & Interval & Jumlah Siswa & Persentase \\
\hline Rendah & $\mathrm{X} \leq 103$ & 3 & $5,4 \%$ \\
\hline Sedang & $103<\mathrm{X} \leq 119$ & 31 & $55,4 \%$ \\
\hline Tinggi & $\mathrm{X}>119$ & 22 & $39,3 \%$ \\
\hline & Jumlah & 56 & $100 \%$ \\
\hline
\end{tabular}

Adapun diukur berdasarkan tingkat persentase ketercapaian skor, diketahui bahwa penyesuian sosial yang ditunjukkan 56 orang siswa/remaja yang mengalami kecanduan mengakses facebook di SMP Negeri 15 Bandung yang menjadi sampel dalam penelitian ini adalah sebesar 78,65\%, lebih tinggi dari angka ketercapaian skor penyesuaian sosial siswa secara keseluruhan yakni $75,5 \%$.

Angka tersebut menunjukkan bahwa lebih dari setengah jumlah siswa yang mengalami kecanduan mengakses facebook masih memiliki penyesuaian sosial yang cukup baik. Persentase ketercapaian skor yang masih cukup tinggi dapat diartikan bahwa siswa yang mengalami kecanduan mengakses facebook dengan kategori tinggi yakni sekitar $75 \%$ memiliki kemampuan penyesuaian sosial dalam tingkat terampil.

$25 \%$ lagi remaja yang mengalami kecanduan mengakses facebook dengan kategori tinggi dinyatakan memiliki kemampuan penyesuaian sosial dalam tingkatan cukup terampil. Kemampuan penyesuaian sosial siswa yang mengalami kecanduan mengakses facebook yang masih berada pada tingkatan terampil dan cukup terampil menunjukkan bahwa siswa masih bersikap wajar dalam pemenuhan kebutuhan dan pergaulannya sehari-hari. Hal ini sejalan dengan pendapat Willis (1992: 43) yang menyatakan bahwa penyesuaian sosial memiliki kaitan yang erat dengan penyesuaian diri dalam konteks individu dengan lingkungannya yakni kemampuan seseorang untuk hidup dan bergaul secara wajar terhadap lingkungannya sehingga ia merasa puas terhadap dirinya dan lingkungannya.

Penyesuaian sosial dalam konteks interaksi sangat berkaitan erat dengan pemenuhan kebutuhan. Dalam melakukan pemenuhan yang baik perlu dilakukan cara-cara pemenuhan kebutuhan yang wajar dan selalu seimbang dari waktu ke waktu. Surya (1977: 15) menjelaskan "untuk memperoleh kelangsungan hidup yang baik individu harus memperoleh keseimbangan diri dalam arti memiliki kebutuhan dan lingkungan".

Meskipun tingkat penyesuaian sosial siswa yang mengalami kecanduan facebook berada pada tingkat terampil dan cukup terampil, apabila tidak ada usaha untuk menjaga keseimbangan dan konsistensinya tidak menutup kemungkinan dapat terjadi perubahan tingkat keterampilan penyesuaian sosial siswa. Surya (1977: 15) lebih lanjut menjelaskan bahwa untuk menjaga 
keseimbangan diri individu harus dapat memuaskan kebutuhan sesuai dengan lingkungannya tanpa mengorbankan kebutuhannya.

Hasil penelitian menunjukkan bahwa untuk pemenuhan kebutuhan remaja mengakses facebook sekitar 53,5\% diantaranya mengorbankan untuk menunda aktivitas lain seperti mengerjakan pekerjaan rumah, mandi, dan aktivitas beribadah. Kondisi objektif seperti ini yang perlu diwaspadai agar tidak merusak keseimbangan yang dimiliki siswa untuk melakukan penyesuaian sosial dalam konteks pemenuhan kebutuhan.

Berikut dipaparkan pembahasan tingkat persentase ketercapaian skor penyesuaian sosial siswa/remaja yang mengalami kecanduan mengakses facebook di SMP Negeri 15 Bandung berdasarkan masing-masing aspek.

Aspek memiliki kemampuan melakukan interaksi interpersonal

Kemampuan siswa dalam melakukan interaksi interpersonal yang dimaksud dalam aspek ini adalah kemampuan remaja untuk berinteraksi secara wajar baik itu dengan teman sebaya, guru maupun staf TU. Tingkat skor ketercapaian kemampuan melakukan interaksi interpersonal remaja yang mengalami kecanduan mengakses facebook dalam aspek ini mencapai 79,4\% lebih tinggi dari skor ketercapaian secara keseluruhan yakni 75,5\%. Angka tersebut menunjukan kemampuan penyesuaian sosial siswa yang mengalami kecanduan mengakses facebook tinggi pada aspek ini berada pada tingkat terampil.

Tingginya skor siswa yang mengalami kecanduan mengakses facebook dibandingkan skor aspek secara keseluruhan siswa dapat disebabkan ketika mereka melakukan aktivitas mengakses facebook, orang-orang yang menjadi partner interaksinya adalah teman nyata mereka baik itu di lingkungan sekolah maupun teman yang mereka kenal akrab di lingkungan tempat mereka tinggal bahkan keluarga mereka sendiri.

Hal ini senada dengan pendapat Brown (2011: 30), "internet juga dapat mempererat hubungan keluarga karena menyediakan fitur yang secara terus menerus dapat menghadirkan keberadaan kita yang berarti internet dapat membuat kita merasa berada dalam jarak yang dekat bahkan merasa berkomunikasi dalam satu ruangan dengan teman atau keluarga yang sedang berada jauh dari kita".

Meskipun partner siswa dalam mengakses facebook adalah orang-orang yang dikenalnya juga di dunia nyata seperti halnya teman sekolah, orang tua dan guru-guru di sekolah tetap harus melakukan pengawasan terhadap aktivitas mereka di dunia maya. Pengawasan yang dapat dilakukan diantaranya adalah mengantisipasi munculnya postingan yang kurang layak di halaman facebook siswa.

Postingan yang kurang layak muncul di halaman facebook siswa seperti katakata kasar yang bernada menjelek-jelekkan berpotensi menjadi sumber 
keretakan hubungan interpersonal antara siswa dengan temannya. Pada akhirnya terganggunya hubungan interpersonal ini dapat menganggu penyesuaian sosial siswa di sekolah. Hal ini diperkuat hasil penelitian yang menunjukkan bahwa sekitar $60 \%$ siswa merasa cemas ada yang menyimpan postingan kurang layak di halaman facebook mereka ketika mereka offline.

Bentuk pengawasan yang dapat dilakukan orang tua atau guru di sekolah yang dapat dilakukan diantaranya menjadi teman para siswa/remaja di situs jejaring sosial tersebut dalam hal ini facebook. Dengan menjadi teman atau masuk ke dalam friendlist siswa di facebook akan meminimalisir siswa meng-update status, menulis komentar atau bahkan mengunggah foto yang kurang layak tampil di ruang publik.

Aspek penyesuaian terhadap tata tertib/peraturan sekolah

Aspek penyesuaian terhadap tata tertib/peraturan sekolah siswa yang mengalami kecanduan mengakses facebook mencapai skor $80,2 \%$ lebih tinggi dari skor aspek keseluruhan siswa kelas VIII yakni 80,0\%. Dengan ketercapaian skor yang cukup baik hal ini menunjukkan bahwa siswa yang mengalami kecanduan mengakses facebook memiliki penyesuaian yang baik terhadap tata tertib/peraturan sekolah.

Kecanduan mengakses facebook secara garis besar memang tidak membuat siswa memiliki hambatan dalam melakukan penyesuaian terhadap tata tertib yang berlaku, namun demikian, berdasarkan hasil penelitian yang telah dilakukan kecanduan mengakses facebook sudah membuat siswa melakukan pelanggaran tata tertib yang berlaku di sekolah. Hal ini ditunjukkan oleh ketercapaian aspek salience yang mencapai 53,5\%. Salah satu bentuk perilaku pada aspek salience siswa yang menunjukkan bahwa siswa melanggar tata tertib di Sekolah ketika sedang mengakses facebook adalah mereka mengakses facebook di saat kegiatan belajar di kelas masih berlangsung.

Apabila tidak ada kontrol dari guru sebagai orang tua siswa di sekolah, bukan tidak mungkin penyesuaian siswa terhadap tata tertib yang berlaku akan terganggu. Penyesuaian siswa terhadap tata tertib yang terganggu akibat perilaku kecanduan mengakses facebook dapat menimbulkan kekhawatiran bagi orang-orang di sekelilingnya. Seperti dinyatakan Young (1999: 8) bahwa "...pecandu bukan satu-satunya orang yang khawatir dan mengantisipasi dampak negatif dari kecanduannya, mereka bahkan cenderung lebih sering melakukannya". Mereka dalam pernyataan Young tersebut ditujukan pada orang-orang di sekeliling pecandu yang memiliki kekhawatiran terhadap perilaku kecanduannya.

Ketercapaian remaja melakukan penyesuaian sosial dalam aspek ini memang berada pada skor $80,02 \%$ dan seperti yang telah dipaparkan sebelumnya maka dapat dikatakan skor yang didapat menunjukkan siswa berada pada tingkatan terampil, namun begitu hasil penelitian menyatakan bahwa terdapat perilaku 
kecanduan siswa mengakses facebook mengarahkan siswa kepada perilaku yang mengganggu penyesuaiannya terhadap tata tertib meskipun angkanya tidak signifikan.

Pengawasan terhadap siswa dalam menggunakan media sosial facebook dapat menjadi salah satu alternatif untuk tetap menguatkan keterampilan siswa/remaja melakukan penyesuaian terhadap tata tertib. Guru dan orang tua merupakan pihak yang dapat membantu melakukan pengawasan, mengawal siswa agar menggunakan facebook pada waktu dan tempat yang seharusnya. Pengawasan yang dapat dilakukan di kelas diantaranya adalah meminta siswa menonaktifkan alat komunikasi yang biasa digunakan untuk mengakses facebook ketika kegiatan belajar masih berlangsung, menonaktifkan sarana yang disediakan sekolah untuk mengakses internet selama jam pelajaran seperti hotspot, memberi sanksi kepada siswa yang melanggar ketentuan dalam mengakses internet sebagai upaya untuk memberikan efek jera.

"Pengawasan ini harus dilakukan dengan disiplin karena disiplin merupakan pelatihan untuk memperbaiki dan menguatkan" (Lindgren, 1972: 266). Disiplin merupakan salah satu bentuk pengendalian diri yang dapat membantu siswa untuk melakukan penyesuaian terhadap tata tertib di sekolah.

Aspek penyesuaian terhadap kelompok belajar

Ketercapaian siswa yang mengalami kecanduan mengakses facebook pada aspek ini mencapai 80,6\% masih lebih tinggi dari skor aspek penyesuaian terhadap kelompok belajar secara keseluruhan. Skor pada aspek ini menjadi skor ketercapaian tertinggi dari empat aspek penyesuaian sosial yang ada.

Hal ini dapat disebabkan oleh interaksi yang intens baik itu di dunia nyata maupun itu melalui media jejaring sosial facebook sehingga dengan keakraban yang terbangun siswa justru menjadi lebih mudah dalam melakukan penyesuaian terhadap kelompok belajarnya. Teman online atau partneronline yang dapat mendukung siswa dalam melakukan penyesuaian yang baik terhadap penyesuaian belajar sebaiknya merupakan teman siswa yang dikenal siswa di dunia nyata. Hal ini sejalan dengan pendapat Halim (2008) yakni "bagi mereka teman online itu tidak lebih baik dari teman sekolah, teman di tempat kerja, atau teman di lingkungan tempat tinggal mereka dalam hal memberikan bantuan dan dukungan emosional".

Mereka dalam pernyataan tersebut merujuk pada pengguna internet dalam hal ini khususnya pengguna situs jejaring sosial facebook. Remaja yang memiliki partner online yang benar-benar dikenalnya, maka dapat membantu remaja memberikan dukungan nyata, baik itu secara fisik maupun secara psikis agar ia mampu melakukan penyesuaian terhadap kelompok belajar.

Penggunaan media sosial facebook dengan bijak dapat menjadi salah satu solusi untuk mempertahankan kemampuan penyesuaian sosial terhadap kelompok belajar. Penggunaan media sosial facebook dengan bijak ini dapat 
dilakukan dengan beberapa hal berikut ini yakni, mengakses facebook hanya pada waktu luang saja, selektif memilih teman dalam friendlist di facebook, dan memanfaatkan facebook tidak hanya sebagai media sosial melainkan juga sebagai media pembelajaran (Nurkamid, Dahlan, Susanto, \& Khotimah, 2010).

Aspek penyesuaian terhadap kegiatan Ekstrakulikuler

Skor ketercapaian aspek penyesuaian terhadap kegiatan ekstrakurikuler merupakan skor terendah yang dicapai siswa yang mengalami kecanduan mengakses facebook dibandingkan ketiga aspek penyesuaian sosial lainnya. Meskipun begitu, skor ketercapaian siswa pada aspek ini yang mencapai $73,8 \%$ masih lebih tinggi dari skor ketercapaian keseluruhan siswa, yakni $68,6 \%$.

Ketercapaian siswa/remaja yang berada pada persentase $73,8 \%$ dapat diartikan bahwa kemampuan penyesuaian sosial remaja terhadap kegiatan ekstrakurikuler berada dalam tingkatan cukup terampil. Kemampuan ini masih harus terus dikembangkan hingga mencapai kemampuan yang optimal.

Kegiatan ekstrakurikuler membantu melatih kecakapan siswa/remaja dalam bekerja sama dan menaruh minat kepada orang lain, melatih cara berinteraksi dan komunikasi, dan melatih siswa mengembangkan kebiasaan yang baik. Penyesuaian remaja terhadap kegiatan ekstrakurikuler di lingkungan sekolah juga membantu mengelola emosi sosial secara wajar, sehingga ketika remaja berada di lingkungan masyarakat ia sudah terampil dalam melakukan penyesuaian sosial. Pernyataan itu sejalan dengan yang diungkapkan Schneider (1964: 454) bahwa lingkungan sekolah merupakan miniatur masyarakat luas dalam menjalin sebuah relasi emosi-sosial dengan orang lain.

Ketercapaian penyesuaian siswa terhadap kegiatan ekstrakurikuler di sekolah yang berada di tingkat cukup terampil masih perlu dikembangkan agar mencapai perkembangan kemampuan siswa yang optimal. Bimbingan kelompok dapat menjadi salah satu alternatif yang dapat dilakukan untuk mengembangkan penyesuaian siswa tehadap kegiatan ekstrakurikuler di sekolah.

\section{SIMPULAN}

Perasaan semangat dan tertantang dalam mengakses facebook, seringnya siswa atau remaja mendapat respon negatif dari keluarga ketika mengakses facebook, dan munculnya perasaan gelisah dan cemas ketika remaja sedang tidak mengakses facebook menjadi indikator yang mendominasi kecanduan siswa mengakses facebook. Berdasarkan penelitian yang telah dilakukan didapatkan data bahwa remaja yang memiliki kecanduan mengakses facebook ini minimal menggunakan dua media. Media yang paling banyak digunakan dalam mengakses facebook oleh siswa SMPN 15 Bandung adalah handphone dan komputer pribadi. 
Kemampuan penyesuaian sosial remaja mayoritas masih berada pada kategori sedang. Kemampuan penyesuaian sosial remaja yang berada dalam kategori sedang dapat juga diartikan bahwa remaja masih cukup terampil dalam melakukan penyesuaian sosial meskipun beberapa diantaranya menunjukkan bahwa remaja yang kecanduan mengakses facebook memiliki kemampuan penyesuaian sosial dalam kategori rendah atau kurang terampil. Hasil penelitian juga menunjukkan kemampuan penyesuaian remaja (siswa SMP) terhadap kegiatan ekstrakurikuler merupakan aspek penyesuaian sosial remaja dengan tingkat ketercapaian paling rendah.

\section{REFERENSI}

ABKIN. (2007). Rambu-Rambu Penyelenggaraan Bimbingan dan Konseling Dalam Jalur Pendidikan Formal. Dirjendikti.

Ahmadi, A. (1999). Psikologi Sosial Edisi Revisi. Jakarta: Rineka Cipta.

Arikunto, S. (2003). Dasar-dasar Evaluasi Pendidikan. Jakarta: Rineka Cipta.

Brown, A. (2011). Relationship, Community and Identity in The New Virtual Society. USA: The Futurist.

Chaplin, F. (1983). Get The Best From People. First Edition. New York: Berkley.

Fitriani, W. (2011). Pemanfaatan Jaringan Facebook sebagai Media Pembelajaran. Tersedia di: winifitriani.blogspot.com (25 Mei 2012)

Gerungan, W.A. (1988). Psikologi Sosial. Jakarta: Eresco.

Griffiths, M. (2000). Does Internet and computer "addiction" exist? Some case study evidence. CyberPsychology and Behavior, 3(2), 211-218.

Halim, D. K. (2008). Psikologi Lingkungan Perkotaan. Jakarta: Bumi Aksara

Hurlock. E B. (1997). Psikologi Perkembangan Sepanjang Rentang Kehidupan. Edisi kelima. Jakarta: Erlangga.

Lindgren, H.C. (1972). Educational Psychology in The Classroom fourth Edition. New York: John Wiley and Son, Inc.

Maria, G. (2008). When You Life Goes Public. Jurnal, 34(7).

Nurkamid, M., Dahlan, M., Susanto, A., \& Khotimah, T. (2010). Pemanfaatan Aplikasi Jejaring Sosial Facebook untuk Media Pembelajaran. Sains dan Teknologi, 3(2), 1-16.

Papalia, D E., Olds, S. W., \& Feldman, Ruth D. (2001). Human development (8th ed.). Boston: McGraw-Hill. 
Qomariyah, A,N. (2008). Perilaku Penggunaan Internet di Kalangan Remaja Perkotaan. Jurnal. Surabaya: Universitas Airlangga.

Rahmadani, S. (2016). Dampak penggunaan situs jejaring sosial terhadap perilaku menyimpang siswa SMA Negeri 3 Makasar. Jurnal Sosialisasi, 3(1), 1-6.

Satrio, E. Y. (2011). Motif dan implikasi penggunaan situs jejaring sosial facebook pada mahasiswa UNNES (Skripsi, Universitas Negeri Semarang).

Schneiders. (1964). Personal Adjustment And Mental Hygiene. New York: Holt Rinehart dan Winston.

Sugiyono. (2010). Metode Penelitian Kuantitatif dan Kualitatif dan $R \& D$. Bandung: Alfabeta.

Surya, M. (1977). Kesehatan Mental Cetakan kedua. Bandung: BP FIP IKIP.

Syahran, R. (2015). Ketergantungan Online Game dan Penanganannya. Jurnal Psikologi Pendidikan dan Konseling, 1(1), 8492.

Wahdah, N. I. (2016). Hubungan kontrol diri dan pengungkapan diri dengan intensitas penggunaan Facebook pada siswa SMP Sunan Giri Malang (Skripsi, Universitas Islam Negeri Maulana Malik Ibrahim).

West, A., Lewis, J., \& Currie, P. (2009). Students' Facebook 'friends': public and private spheres. Journal of Youth Studies, 12(6), 615-627.

Young, K. S. (1999). Internet addiction: symptoms, evaluation and treatment. Innovations in clinical practice: A source book, 17, 19-31.

Young, K., Pistner, M., O'mara, J, \& Buchanan, J. (1999). Cyber disorders: the mental health concern for the new millennium. CyberPsychology \& Behavior, 2(5), 475-479.

Young, K. S., \& De Abreu, C. N. (Eds.). (2010). Internet addiction: A handbook and guide to evaluation and treatment. New Jersey: John Wiley \& Sons, Inc. 